ks. Piotr Kroczek

Uniwersytet Papieski

Jana Pawła II w Krakowie
Eliminacja wykluczenia społecznego, red. M. Duda, K. Kutek-Sładek, Kraków 2017, s. 5-19 (Praca Socjalna w Teorii i Działaniu, 3).

DOI: http://dx.doi.org/10.15633/9788374385824.01

\title{
Ocena regulacji w prawie Kościoła katolickiego dotyczących profilaktyki spolecznej w kontekście prawa polskiego
}

\author{
Evaluation of social prevention in law \\ of the Catholic Church in the context of Polish law - \\ summary
}

\begin{abstract}
These days one can observe a huge interest in social prevention in Poland. Many institutions and organs of Polish state authorities and of the local state authorities are engaged in the activity in question. The Church, of course, due to the fact that it is a visible association and a spiritual community, which goes forward together with humanity and experiences the same earthly lot which the world does (GS 40), has a moral obligation to strive for the good of the whole society, not only for the good of the faithful. The paper aims to investigate whether the Catholic Church legislation contains any rules about the matter of social
\end{abstract}

prevention. Both, universal church law and particular church law are analyzed. The main conclusion is that the church legislative bodies do not use thoroughly the possibilities given by Polish state law to involve the Church, which is still an important element of social life in Poland, in the social prevention actions. Changing the situation would be of help to fulfill the missions of the Church and would contribute to strengthening of the Church's position in Poland.

Keywords: social prevention, Poland, Catholic Church, legislation 


\section{Postawienie problemu}

Obecny wzrost powszechnego zainteresowania profilaktyką społeczną, z uwagi na sytuację społeczeństwa w Polsce, jest uzasadniony i zrozumiały ${ }^{1}$. Wiele instytucji rządowych i pozarządowych zaangażowanych jest w różnego rodzaju projekty profilaktyczne. Zwykle zadania te mają, po pierwsze, diagnozować i opisywać zjawiska mające wpływ na stan społeczeństwa, grup społecznych czy jednostek. Po drugie - mają one, poprzez odpowiednie działania, zapobiegać niepożądanym zjawiskom społecznym i zapobiegać patologiom w rozwoju społeczeństwa. Tak ujęta profilaktyka społeczna może także skutecznie redukować przypadki patologii społecznej i przyczyniać się do osłabienia lub nawet ich eliminacji. Może także immunizować życie społeczne wobec tych zagrożeń ${ }^{2}$.

Kościół katolicki jest ciągle ważnym elementem życia społecznego w Polsce. Silnie oddziałuje na szerokie warstwy społeczne. Pytanie, które w tym kontekście można zadać, dotyczy prawnych możliwości zaangażowania Kościoła w profilaktykę społeczną, czy to na zasadzie samodzielnie podejmowanych działań, czy też współpracy $\mathrm{z}$ innymi podmiotami.

W niniejszym artykule zostaną przedstawione kolejno: racje przemawiające za włączeniem się Kościoła w ogół działań zapobiegających niepożądanym zjawiskom społecznym, regulacje kanonicznego prawa powszechnego i kanonicznego prawa partykularnego obowiązującego w Polsce, które zawierają przepisy dotyczące zaangażowania Kościoła w profilaktykę społeczną. Następnie zostanie dokonana ocena tych regulacji na tle możliwości stwarzanych przez prawo polskie. Całość zamkną wnioski i postulaty wobec prawodawcy kościelnego.

1 Literatura w tym zakresie jest bardzo obszerna, np.: M. Pawlak, Profilaktyka społeczna i resocjalizacja, Warszawa 2014; E. Rajewska-Nikonowicz, E. Gołaszewska, Profilaktyka instytucjonalna - województwo podlaskie, Białystok 2014; M. Zajdel-Ostrowska, Profilaktyka instytucjonalna w woj. podkarpackim w 2013 r., Rzeszów 2014; T. Wach, Profilaktyka i resocjalizacja nieletnich zagrożonych uzależnieniem od środków psychoaktywnych, Warszawa 2014; M. Przybysz-Zaremba; T. Butvilas, Profilaktyka narkotykowa w szkole, „Pedagogika Społeczna" 13 (2014) nr 3, s. 105-117; Patologie społeczne, przestępczość, niedostosowanie społeczne. Wyzwania dla współczesnej profilaktyki, red. M. Jędrzejko, W. Gładysz, Warszawa 2014; S. Cudak, Profilaktyka zagrożeń dzieci i młodzieży, Łódź-Warszawa 2015; J. Utrat-Milecki, Aktualność programu profilaktyki społecznej i resocjalizacji na Uniwersytecie Warszawskim, „Profilaktyka Społeczna i Resocjalizacja” (2015) 25, s. 163-179.

2 Por. D. Urbaniak-Zając, J. Piekarski, Profilaktyka społeczna (prewencja), [w:] Elementarne pojęcia pedagogiki społecznej i pracy socjalnej, red. E. Latak, T. Pilch, Warszawa 2012, s. 215; K. Borzucka-Sitkiewicz, K. Kowalczewska-Grabowska, Profilaktyka społeczna. Aspekty teoretyczno-metodyczne, Katowice 2013, s. 73-75. 


\section{Czy Kościół powinien zajmować się profilaktyka społeczną?}

Pierwszym celem Kościoła jest „bycie sakramentem wewnętrznego zjednoczenia ludzi z Bogiem" (KKK $\left.{ }^{3} 775\right)$. W celu realizacji tego powołania Kościół wypełnia tria munera sacra: uświęcanie, rządzenie, nauczanie. W optyce Kościoła jest, co zrozumiałe, w pierwszej kolejności dobro Kościoła jako communio i dobro każdego wiernego. Wielokrotnie w dokumentach Kościoła o charakterze doktrynalnym i normatywnym jest mowa właśnie o „dobru Kościoła” (bonum Ecclesiae) w różnych wariantach (np. kan. $223 \$ 1$, kan. $282 \$ 2$, kan. 345, kan. 618, kan. $1299 \$ 2$; $\mathrm{CD}^{4} 25, \mathrm{AA}^{5} 24, \mathrm{PO}^{6} 10$ ), czy też o „dobru wiernych” (fidelium bonum) (np. kan. 88, kan. 1233; $\mathrm{LG}^{7} 22$ ).

Jednakże Kościół, „stanowiąc zarazem zrzeszenie dostrzegalne i wspólnotę duchową, kroczy razem z całą ludzkością i doświadcza tego samego losu ziemskiego co świat, istniejąc w nim jako zaczyn i niejako dusza społeczności ludzkiej, która ma się w Chrystusie odnowić i przemienić w rodzinę Bożą" (GS ${ }^{8} 40$ ). Kościół, działając w świecie, nie może być obojętny na warunki, w których żyją jego wierni. Dlatego też swoją troską obejmuje osoby niebędące jego członkami. Jest tak dlatego, że każdy człowiek z racji jego godności stworzenia i odkupienia jest drogą Kościoła - „pierwszą i podstawową drogą Kościoła, drogą wyznaczoną

3 Katechizm Kościoła Katolickiego, Poznań 2002.

4 Sacrosanctum Concilium Oecumnicum Vaticanum II, Decretum Christus Dominus de pastorali episcoporum, 28 października 1965 r., „Acta Apostolicae Sedis” [dalej: AAS] 58 (1966), s. 673-696; tekst polski: Sobór Watykański II, Dekret o pasterskich zadaniach biskupów w Kościele Christus Dominus, [w:] Sobór Watykański II, Konstytucje, dekrety, deklaracje, Poznań 1968, s. 232-254.

5 Sacrosanctum Concilium Oecumenicum Vaticanum II, Decretum Apostolicam actuositatem de apostolatu laicorum, 15 listopada 1965 r., AAS 58 (1966), s. 837-864; tekst polski: Sobór Watykański II, Dekret o apostolstwie świeckich Apostolicam actuositatem, [w:] Sobór Watykański II, Konstytucje, dekrety, deklaracje, dz. cyt., s. 379-405.

6 Sacrosanctum Concilium Oecumenicum Vaticanum II, Decretum Presbyterorum ordinis de presbyterorum ministerio et vita, 7 grudnia 1965 r., AAS 58 (1966), s. 991-1024; tekst polski: Sobór Watykański II, Dekret o posłudze i życiu kapłanów Presbyterorum ordinis, [w:] Sobór Watykański II, Konstytucje, dekrety, deklaracje, dz. cyt., s. 487-517.

7 Sacrosanctum Concilium Oecumenicum Vaticanum II, Constitutio dogmatica $\mathrm{Lu}$ men gentium de Ecclesia, 21 listopada 1964 r., AAS 57 (1965), s. 5-75; tekst polski: Sobór Watykański II, Konstytucja dogmatyczna o Kościele Lumen gentium, [w:] Sobór Watykański II, Konstytucje, dekrety, deklaracje, dz. cyt., s. 105-170.

8 Sacrosanctum Concilium Oecumenicum Vaticanum II, Constitutio pastoralis Gaudium et spes de Ecclesia in mundo huius temporis, 7 grudnia 1965 r., AAS 58 (1966), s. 1025-1115; tekst polski: Sobór Watykański II, Konstytucja duszpasterska o Kościele w świecie współczesnym Gaudium et spes, [w:] Sobór Watykański II, Konstytucje, dekrety, deklaracje, dz. cyt., s. 537-620. 
przez samego Chrystusa”" Sobór Watykański II stwierdził, że Kościół chce, aby „życie ludzkie na ziemi uczynić godnym człowieka” (GS 91). Kościół „niczego goręcej nie pragnie, jak żeby służąc dobru wszystkich, mógł swobodnie się rozwijać pod jakimkolwiek rządem, uznającym fundamentalne prawa osoby i rodziny oraz potrzeby wspólnego dobra” (GS 20). „Dobro wspólne” w ujęciu soborowym to suma warunków życia społecznego, które pozwalają osiągać pełniej i łatwiej własną doskonałość zarówno zrzeszeniom ludzkim, jak i poszczególnym członkom społeczeństwa. Każda grupa społeczna, także Kościół, musi uwzględnić potrzeby i słuszne dążenia innych grup, co więcej, także dobro wspólne całej rodziny ludzkiej (GS 26).

Przedstawiona powyżej doktrynalna postawa otwarcia Kościoła na każdą formę dobra ludzkiego jest podstawą do stanowienia prawa kanonicznego umożliwiającego i stwarzającego ramy dla prospołecznej działalności Kościoła, także dla profilaktyki społecznej realizowanej przez Kościół.

\section{Regulacje prawa kanoniczego dotyczace profilaktyki społecznej}

Stanowiąc prawo kościelne, prawodawca musi mieć w optyce $\mathrm{z}$ jednej strony doktrynę Kościoła, a z drugiej strony potrzeby związane ze specyfiką miejsca i czasu stanowienia prawa, jego aplikacji oraz pozakościelnych determinantów prawodawstwa, do których w omawianym kontekście należy zaliczyć przede wszystkim prawo państwowe ${ }^{10}$.

\subsection{Prawo powszechne}

Prawo powszechne katolickiego Kościoła łacińskiego zawarte głównie w Kodeksie prawa kanonicznego z 1983 roku $^{11}$ w kilku miejscach dotyka profilaktyki społecznej.

9 Joannes Paulus PP. II, Litterae apostolicae Redemptor hominis Iesus Christus est centrum universi et historiae, 4 marca 1979, AAS 71 (1979), s. 257-324; tekst polski: Nauczanie Ojca Świętego Jana Pawła II, Komputerowy zbiór dokumentów papieskich, CD-ROM, Wydawnictwo M, wersja 1 z 1999 r., tu nr 14.

10 P. Kroczek, The Art of legislation: the principles of lawgiving in the Church, 2nd rev. ed., Kraków 2012, s. 131-132.

${ }_{11}$ Codex Iuris Canonici auctoritate Ioannis Pauli PP. II promulgatus, AAS 75 (1983), cz. 2, s. 1-318, a ich tłumaczenie pochodzi z przekładu zatwierdzonego przez Konferencję Episkopatu Polski, Kodeks prawa kanonicznego, tekst łacińsko-polski, Poznań 1984. Cytowane w tym artykule kanony odnoszą się do tego aktu normatywnego. 
Ogólna regulacja dotycząca przedmiotowej materii zawarta jest w kan. 747 $\$ 2$ - „Kościołowi przysługuje prawo głoszenia zawsze i wszędzie zasad moralnych również w odniesieniu do porządku społecznego, oraz wypowiadania oceny o wszystkich sprawach ludzkich, na ile wymagają tego fundamentalne prawa osoby ludzkiej i zbawienie człowieka". Bez wątpienia także sprawy społeczne związane z profilaktyką należą do zakresu wskazanego w tym przepisie. Pouczanie więc o nich, o ile mają jakiś związek z moralnością, należy do własnych i wrodzonych kompetencji Kościoła.

Kodeks zawiera także bardziej szczegółowe regulacje w omawianym obszarze życia. W kan. $255 \$ 2$ nakazuje się, aby alumnów seminariów zapoznawać z potrzebami całego Kościoła, ale także ze sprawami misyjnymi i ekumenicznymi oraz sprawami społecznymi. Władzy kościelnej zależy więc na tym, aby nauka Kościoła dotycząca człowieka w wymiarze zarówno wiecznym, jak i doczesnym była podawana w sposób odpowiedni i przystosowany do ich mentalności i do aktualnych potrzeb (por. kan. 248).

Innym miejscem w kodeksie, w którym można dostrzec pewne regulacje związane z profilaktyką społeczną, są przepisy dotyczące stowarzyszeń wiernych. Wprawdzie prawodawca kościelny nie umieszcza w katalogu celów, które mogą mieć stowarzyszenia wiernych, celów profilaktyki społecznej (zob. kan. 215 i w kan. $298 \$ 1$ ), jednakże istnieją pewne przesłanki, aby takie cele wyinterpretować z przepisów. Zgodnie bowiem z kan. $304 \$ 1$ statut stowarzyszenia powinien mieć przedmiot społeczny (obiectum sociale). Prawodawca nie użył zwrotu - przykładowo - „przedmiot wspólnotowy”, co odnosiłoby się bezpośrednio do wspólnoty Kościoła (communio) i zawężało cele do stricte religijnych. Przy obowiązującym brzmieniu omawianego kanonu można powiedzieć, że każdy cel związany z dobrem człowieka czy dobrem wspólnoty ludzkiej, o ile tylko ma rys katolicki i zmierza do apostolstwa, jest prawnym celem stowarzyszenia wiernych. Tym samym otwarta została możliwość działalności tych ruchów kościelnych, które za cel stawiają sobie profilaktykę społeczną ${ }^{12}$.

Z kolei w przepisach dotyczących wychowania kodeks nakazuje, aby wychowanie obejmowało pełną formację osoby ludzkiej, zarówno w odniesieniu do celu ostatecznego człowieka, jak i w odniesieniu do celu, jakim jest dobro wspólne różnych społeczności ziemskich. Prawodawca nakazuje przygotowywać młode pokolenie do czynnego udziału w życiu społecznym (kan. 795). Ten obowiązek spoczywa w pierwszej kolejności na rodzicach (kan. 1136), którzy

12 Zob. P. Kroczek, Cele stowarzyszeń wiernych świeckich i ich realizacja na przykładzie wybranych stowarzyszeń działających w Diecezji Bielsko-Żywieckiej, [w:] W prostocie prawdy, w pokorze miłości. Studia i materialy dedykowane księdzu prof. zw. dr. hab. Janowi Walowi, red. T. Borutka, A. Baczyński, M. Ostrowski, Kraków 2008, s. 313-322. 
mogą korzystać z pomocy różnych instytucji, a szczególnie szkół (kan. 796 $\$ 1)$. Pośrednio więc prawodawca kościelny widzi możliwość praktycznego odnoszenia się do wszystkich form pomocy społeczeństwu, także przez profilaktykę społeczną praktykowaną przez ośrodki czy organy o umocowaniu pozakościelnym. Oczywiście taka zgoda nie oznacza wcale zgody na wszystkie treści przekazywane poprzez wymienione działania.

Sumując, można powiedzieć, że regulacje w prawie powszechnym Kościoła dotyczące przedmiotowej materii cechuje duży stopień ogólności. Takie rozwiązanie prawodawcze jest w pełni uzasadnione. To prawo powszechne jest bowiem stanowione dla Kościoła działającego na całym świecie. Oznacza to, że potencjalnie będzie ono aplikowane w całej gamie różnorodnych warunków społecznych. Zadaniem tego prawa jest stworzenie pewnych ram dla działalności Kościoła, w tym także pracy na rzecz społeczeństwa w wymiarze profilaktyki społecznej oraz, poprzez zasadę pomocniczości, danie możliwości specyficznej regulacji tej dziedziny w prawie partykularnym ${ }^{13}$.

\subsection{Prawo partykularne obowiąujące w całej Polsce}

Gdy chodzi o polskie prawo partykularne, to stosując się do wspomnianej zasady pomocniczości, poświęca ono sprawom społecznym, w tym także i profilaktyce społecznej, nieco więcej miejsca niż prawo powszechne Kościoła, aczkolwiek nie są to regulacje rozbudowane. Wypada najpierw omówić prawo obowiązujące we wszystkich diecezjach polskich, a następnie podać przykładowe regulacje obowiązujące w ramach niektórych diecezji.

Jeżeli chodzi o prawo kanoniczne obowiązujące we wszystkich diecezjach Kościoła katolickiego w Polsce, to kluczowym dokumentem normatywnym są uchwały II Polskiego Synodu Plenarnego ${ }^{14}$. Zwraca się w nich uwagę, że działania profilaktyczne w społeczeństwie to działalność wchodząca w zakres chrześcijańskiej posługi miłosierdzia. Podkreśla się, że pełniąc tę posługę, trzeba usuwać przede wszystkim przyczyny zła, a nie tylko jego skutki. „Obok charytatywnej terapii i profilaktyki realizowanej jako pomoc osobowa należy przede wszystkim oddziaływać na struktury życia społecznego, aby bardziej skutecznie chroniły słabszych i gwarantowały wszystkim równy dostęp do dobra wspólnego"15.

13 Na temat tej zasady w Kościele w kontekście kościelnego poradnictwa rodzinnego zob. P. Kroczek, Kościelne poradnictwo rodzinne: stan prawny i postulaty de lege ferenda, [w:] Wyjechać czy pozostać? Wokół dylematów rynku pracy, red. M. Duda, B. Majerek, Kraków 2015, s. 281.

14 II Polski Synod Plenarny (1991-1999), Poznań 2001 [dalej: Synod Plenarny].

15 Synod Plenarny, Kościół wobec życia społeczno-gospodarczego, nr 57. 
Znów należy uznać, że niewielki zakres regulacji prawnych ustanowionych przez biskupów na poziomie ogólnopolskim to sposobność dla poszczególnych biskupów diecezjalnych, aby znając realia swoich Kościołów partykularnych, powierzonych ich pasterskiej pieczy, stanowili prawo, które odpowiadać będzie miejscowym warunkom. Oczywiście, możliwa jest także teza, że obecny stan prawny to po prostu zaniedbanie przez Konferencję Episkopatu Polski troski w wymiarze legislacyjnym o udział Kościoła w Polsce w sprawach profilaktyki społecznej.

\subsection{Prawo partykularne diecezjalne}

Diecezje w Polsce na swoim terenie mają ustawodawstwo, które zawiera regulacje dotyczące profilaktyki społecznej. Jest to głównie prawo ustanowione na synodach diecezjalnych. Synod diecezjalny to „zebranie wybranych kapłanów oraz innych wiernych Kościoła partykularnego, którzy dla dobra całej wspólnoty diecezjalnej świadczą pomoc biskupowi diecezjalnemu" (kan. 460). Należy także zauważyć, że na synodzie diecezjalnym dogmatycznym prawodawcą, czyli prawodawcą de iure divino, jest biskup diecezjalny (kan. 466, CD 8) ${ }^{16}$. On, nie mogąc delegować władzy ustawodawczej (kan. $135 \$ 2$ ), bierze pełną odpowiedzialność za stanowione prawo. Poniżej przedstawiono przykładowe, dobrane losowo regulacje synodalne w przedmiotowym zakresie.

\subsubsection{Archidiecezja białostocka}

Dla przykładu można podać, że I Synod Archidiecezji Białostockiej ${ }^{17}$ uchwalił, że Duszpasterstwo Osób Uzależnionych nie tylko obejmuje troską pasterską, pełną miłości chorych pogrążonych w różnego typu nałogach, którym należy pomóc z nich powstać, ale także ma objąć swoją działalnością wiernych zagrożonych uzależnieniami, czyli prowadzić profilaktykę.

Także w statucie Caritas Archidiecezji Białostockiej ${ }^{18}$ zapisano, że jej cel zasadniczy, jakim jest szerzenie oraz praktykowanie nauki Jezusa Chrystusa o miłosierdziu chrześcijańskim, jest realizowany w szczególności przez organizowanie i prowadzenie różnego typu poradni ${ }^{19}$.

16 Zob. szerzej, np. M. Wijlens, For you I am a bishop. With you I am a Christian, „The Jurist” (1996) 56, s. 68-91; National Conference of Catholic Bishops, A manual for bishops. Rights and responsibilities of diocesan bishops in the revised Code of canon law, Washington 1992, s. 27-36.

17 I Synod archidiecezji białostockiej, Białystok 2000.

18 I Synod archidiecezji białostockiej, Księga aneksów, b.n.s.

19 Cele i zadania Caritas Archidiecezji Białostockiej, pkt 5, [w:] I Synod archidiecezji białostockiej, Księga aneksów, Białystok 2000, b.n.s. 


\subsubsection{Archidiecezja warszawska}

Z kolei w statutach IV Synodu Archidiecezji Warszawskiej ${ }^{20}$, w części dotyczącej duszpasterstwa uzależnionych, profilaktyka w zakresie uzależnień została powierzona parafii. Temu celowi winny służyć: „nauczanie katechetyczne na wszystkich szczeblach, konferencje przedmałżeńskie dla narzeczonych, konferencje stanowe podczas rekolekcji, niektóre uroczystości religijne o charakterze pokutnym, przygotowanie do pierwszej Komunii świętej i sakramentu bierzmowania i tym podobne"21. Duszpasterze powinni, otaczając troską uzależnionych, podjąć współpracę z zespołami i organizacjami zajmującymi się tymi osobami i ich problemami ${ }^{22}$. Nakazano także, aby troską duszpasterską objąć rodziny osób uzależnionych ${ }^{23}$.

\subsubsection{Archidiecezja gdańska}

III Synod Gdański ${ }^{24}$ dokonał recepcji i uszczegółowienia przedstawionych wyżej norm kościelnego prawa powszechnego dotyczących obowiązku zapoznania alumnów seminaryjnych z problemami społecznymi. Ma to służyć - jak podkreślono - efektywniejszej i pełniejszej posłudze duszpasterskiej ${ }^{25}$.

Synod ten wiele miejsca poświęcił również duszpasterstwu trzeźwości ${ }^{26}$. Podkreślono, że celem tego duszpasterstwa jest nie tylko pomoc osobom uzależnionym, ale także szerzenie cnoty trzeźwości, aby „ludzie używali napojów alkoholowych, kierując się rozumem i wiarą" ${ }^{27}$. Środkiem do tego celu jest działalność informacyjna, pomagająca w zmianie błędnych sposobów myślenia oraz groźnych postaw i obyczajów społecznych. W odniesieniu nie tylko do alkoholu, ale także do nikotyny i narkotyków ${ }^{28}$.

20 IV Synod archidiecezji warszawskiej, Warszawa 2003 [dalej: Synod warszawski].

21 Synod warszawski, Statut nr 421.

22 Synod warszawski, Statut nr 423.

23 Synod warszawski, Statut nr 421.

24 III synod gdański. Misja ewangelizacyjna Kościoła gdańskiego na początku nowego tysiąclecia, t. 1, Statuty, Gdańsk 2001, dalej: Synod gdański.

${ }_{25}$ Synod gdański nr 938.

26 Synod gdański nr 917-921.

27 Synod gdański nr 917.

28 Synod gdański nr 917. 


\section{Regulacje prawa polskiego dotyczace działalności Kościoła na rzecz profilaktyki społecznej}

Aby móc w pełni ocenić stan legislacji kanonicznej na tle prawodawstwa polskiego, należy przyjrzeć się, czy ustawodawca polski przewidział dla Kościoła katolickiego miejsce w działalności związanej z profilaktyką społeczną.

Trzeba na wstępie przypomnieć jedną z zasad kształtujących relacje pomiędzy państwem a Kościołem i związkami wyznaniowymi w Polsce. Chodzi o zasadę równouprawnienia względem państwa i prawa państwowego wspomnianych zrzeszeń religijnych. Normę o tej treści zawiera art. 25 ust. 1 Konstytucji RP, w którym ustrojodawca postanowił, że „Kościoły i inne związki wyznaniowe są równouprawnione" ${ }^{29}$. Oznacza to, że żaden Kościół czy związek wyznaniowy nie jest uprzywilejowany prawnie ${ }^{30}$.

W konsekwencji należy przyjąć, że to, co dotyczy Kościoła katolickiego, dotyczy również, mutatis mutandis, także i innych Kościołów oraz związków wyznaniowych. Oczywiście, należy uwzględnić sposób obecności danego zrzeszenia religijnego w systemie prawa polskiego. Regulacja prawna działalności Kościoła lub związku wyznaniowego może mieć formę specjalnej ustawy, rejestracji lub faktycznej, lecz niezarejestrowanej administracyjnie działalności. Zgodnie z orzecznictwem Trybunału Konstytucyjnego można zastosować także i inne kryteria podziału czy rozróżnienia. Nie będzie to przejawem dyskryminacji, o ile różnicowanie to będzie usprawiedliwione ${ }^{31}$.

W przedmiotowym zakresie działalności profilaktycznej na rzecz społeczeństwa prawo polskie przewiduje kilka form obecności Kościoła. Oto niektóre z nich.

\subsection{Rada Pomocy Społecznej}

Do zadań Rady Pomocy Społecznej, czyli do organu opiniodawczo-doradczego w sprawach pomocy społecznej, działającego przy ministrze właściwym do spraw zabezpieczenia społecznego (obecnie jest to Ministerstwo Pracy i Polityki Społecznej) należy m.in. opiniowanie projektów aktów prawnych oraz

29 Szeroko o tym pisze D. Dudek, Równouprawnienie kościołów i związków wyznaniowych na tle konstytucyjnych zasad prawa wyznaniowego, [w:] Prawo wyznaniowe w systemie prawa polskiego. Materiały I Ogólnopolskiego Sympozjum Prawa Wyznaniowego (Kazimierz Dolny, 14-16 stycznia 2003), red. A. Mezglewski, Lublin 2004, s. 199-225.

30 W. Skrzydło, Konstytucja Rzeczpospolitej Polskiej. Komentarz, Kraków 2002, s. 36.

31 Wyrok Trybunału Konstytucyjnego z dnia 7 czerwca 2004 r., P 4/03, Legalis nr 63693; wyrok Trybunału Konstytucyjnego z dnia 14 grudnia 2009 r., K 55/07, Legalis nr 180038 . 
inicjowanie zmian przepisów prawa w zakresie pomocy społecznej oraz przygotowywanie ekspertyz dotyczących wybranych obszarów pomocy społecznej (art. 124 ust. 2 u.p.s.). We wskazanym zakresie mieszczą się szeroko pojęte działania profilaktyczne określone $\mathrm{w}$ aktach prawnych wydawanych przez kompetentne ograny państwowe.

Do tej rady należeć mogą osoby reprezentujące Kościoły i inne związki wyznaniowe (art. 124 ust. 1 i art. 125 ust. 1 u.p.s. ${ }^{32}$ ). W obecnej, VII kadencji Rady, przewidzianej na lata 2014-2017, nie ma przedstawiciela Kościoła katolickiego ani żadnej organizacji związanej z Kościołem ${ }^{33}$. Według danych uzyskanych z Departamentu Pomocy i Integracji Społecznej Ministerstwa Pracy i Polityki Społecznej do wspomnianej Rady z ramienia Kościoła katolickiego należeli: w czasie II kadencji o. Hubert Matusewicz i ks. Marian Subocz, zaś w czasie III kadencji - ks. Wojciech Łazewski ${ }^{34}$. Innych przedstawicieli Kościoła nie było.

\subsection{Strategia rozwoju \\ jednostek samorządu terytorialnego}

Kolejną możliwość obecności w działaniach prospołecznych w zakresie profilaktyki społecznej otwiera dla Kościoła strategia rozwoju jednostek samorządu terytorialnego.

Każde województwo powinno mieć strategię własnego rozwoju (art. 11 u.s.w. ${ }^{35}$ ). Integralną częścią tego planu jest strategia w zakresie polityki społecznej. Obejmować ma ona w szczególności programy: przeciwdziałania wykluczeniu społecznemu, wyrównywania szans osób niepełnosprawnych, pomocy społecznej, profilaktyki i rozwiązywania problemów alkoholowych, współpracy z organizacjami pozarządowymi (art. 21 pkt 1 u.p.s. ${ }^{36}$ ).

Opracowanie, aktualizowanie i realizacja strategii należy do zadań samorządu województwa (art. 11 ust. 1 u.s.w.). Samorząd przy formułowaniu tej strategii i realizacji polityki jego rozwoju ma, zgodnie z art. 12 ust. 1 pkt 4 ustawy o samorządzie województwa, obowiązek współpracować w szczególności z organizacjami pozarządowymi oraz podmiotami wymienionymi w art. 3 ust. 3 ustawy

32 Ustawa z dnia 12 marca 2004 r. o pomocy społecznej, Dz.U. z 2015 r. poz. 163 z późn. zm.

33 www.mpips.gov.pl/pomoc-spoleczna/rada-pomocy-spolecznej (dostęp: 31.08.2015).

34 Pismo nr Ldz. 8659 o sygnaturze BPM-II.051.307.2015.KK z dnia 28 października 2015 r. będące odpowiedzią na wniosek o udostępnienie informacji publicznej (archiwum autora).

35 Ustawa z dnia 5 czerwca 1998 r. o samorządzie województwa, Dz.U. z 2013 r. poz. 596 z późn. $z m$.

36 Ustawa z dnia 12 marca 2004 r. o pomocy społecznej, Dz.U. z 2015 r. poz. 163 z późn. zm. 
z dnia 24 kwietnia 2003 r. o działalności pożytku publicznego i o wolontariacie ${ }^{37}$. Należą do nich m.in. osoby prawne i jednostki organizacyjne działające na podstawie przepisów o stosunku państwa do Kościoła katolickiego w Rzeczypospolitej Polskiej ${ }^{38}$, a więc m.in. diecezje, parafie (art. 7 u.s.p.k.k.) czy organizacje kościelne i organizacje katolickie (art. 34 i 35 u.s.p.k.k.), jeżeli ich cele statutowe obejmują prowadzenie działalności pożytku publicznego.

Współpraca w przedmiotowej materii ma prawne podwaliny także w ustawie o pomocy społecznej ${ }^{39}$ na poziomie powiatu i gminy. Do zadań własnych powiatu należy opracowanie i realizacja powiatowej strategii rozwiązywania problemów społecznych, ze szczególnym uwzględnieniem programów pomocy społecznej, wspierania osób niepełnosprawnych i innych, których celem jest integracja osób i rodzin z grup szczególnego ryzyka (art. 19 pkt 1 u.p.s). Natomiast do zadań z zakresu administracji rządowej zleconych powiatowi należy realizacja zadań wynikających z rządowych programów pomocy społecznej, mających na celu ochronę poziomu życia osób, rodzin i grup społecznych oraz rozwój specjalistycznego wsparcia (art. 20 ust. 1 pkt 3 u.p.s.). Z kolei do zadań własnych gminy o charakterze obowiązkowym należą: opracowanie i realizacja gminnej strategii rozwiązywania problemów społecznych ze szczególnym uwzględnieniem programów pomocy społecznej, profilaktyki i rozwiązywania problemów alkoholowych i innych, których celem jest integracja osób i rodzin z grup szczególnego ryzyka (art. 17 ust. 1 pkt 1 u.p.s.).

\subsection{Zadania oświatowe}

jednostek samorzadu terytorialnego

Jednostki samorządu terytorialnego: województwa, powiaty i gminy mają zlecone ustawą pewne zadania oświatowe. Należą do nich zadania w zakresie kształcenia, wychowania i opieki, w tym profilaktyki społecznej (art. 3 pkt 14 u.s.o. ${ }^{40}$ ). Dotyczą one głównie zapewnienia kształcenia, wychowania i opieki, w tym kształcenia specjalnego i profilaktyki społecznej (art. 5a ust. 2 u.s.o.). Kościół, poprzez swoje osoby prawne, współpracując z placówkami oświatowymi, może uczestniczyć we wymienionych zadaniach.

37 Dz. U. z 2010 r. Nr 234, poz. 1536 z późn. zm.

38 Ustawa z dnia 17 maja 1989 r. o stosunku Państwa do Kościoła Katolickiego w Rzeczypospolitej Polskiej, Dz.U. z 2013 r. poz. 1169 z późn. zm. [dalej: u.s.p.k.k.].

39 Ustawa z dnia 12 marca 2004 r. o pomocy społecznej, Dz.U. z 2015 r. poz. 163 z późn. zm. [dalej: u.p.s.].

40 Ustawa z dnia 7 września 1991 r. o systemie oświaty, Dz.U. Nr 256, poz. 2572 z późn. zm. 


\subsection{Działania antyalkoholowe i antynarkotykowe}

Duże pole do działalności profilaktycznej kościelnych podmiotów daje ustawa o wychowaniu w trzeźwości i przeciwdziałaniu alkoholizmowi ${ }^{41}$. Zawiera ona expressis verbis nakaz, skierowany do organów administracji rządowej i jednostek samorządu terytorialnego, podejmowania działań zmierzających do realizacji celów tej ustawy - czyli zasadniczo do ograniczania spożycia napojów alkoholowych - do współdziałania z Kościołem katolickim (art. 1 ust. 3 u.w.t.).

Podobnie jest w ustawie o przeciwdziałaniu narkomanii ${ }^{42}$. W realizacji celów tej ustawy mogą uczestniczyć organizacje pozarządowe i inne podmioty, których działalność statutowa obejmuje zadania należące do sfery zadań publicznych w zakresie ochrony i promocji zdrowia, pomocy społecznej, działalności charytatywnej, nauki, edukacji, oświaty i wychowania, kultury fizycznej, porządku i bezpieczeństwa publicznego lub przeciwdziałania patologiom społecznym, promocji i organizacji wolontariatu (art. 5 ust. 3 u.p.n.). Wskazanymi podmiotami mogą być także stowarzyszenia wiernych czy kościelne fundacje.

\subsection{Ocena otwarcia ustawodawcy polskiego na stronę kościelna}

Oceniając stan prawny regulujący res mixtae, do których należy profilaktyka społeczna, można powiedzieć, że w prawie polskim dobro wspólne obywateli, którzy są jednocześnie wiernymi Kościoła, zostało zabezpieczone. Może się ono powiększać i jeszcze bardziej służyć rozwojowi człowieka.

Po tym krótkim wyliczeniu możliwych obszarów działalności Kościoła w sferze profilaktyki społecznej należy stwierdzić, że regulacje prawa państwowego w tym zakresie umożliwiają szerokie oddziaływanie Kościoła katolickiego na społeczeństwo, głównie poprzez podejmowanie współpracy z organami terytorialnej władzy samorządowej.

\section{Wnioski}

Oceniając kościelne prawo partykularne obowiązujące w diecezjach polskich dotyczące profilaktyki społecznej, należy stwierdzić, że liczba aktów normatywnych jest niewielka, a ich zakres regulacyjny wąski. Prawodawstwo kościelne

41 Ustawa z dnia 26 października 1982 r. o wychowaniu w trzeźwości i przeciwdziałaniu alkoholizmowi, Dz.U. z 2012 r. poz. 1356 z późn.zm. [dalej: u.w.t.].

42 Ustawa z dnia 29 lipca 2005 r. o przeciwdziałaniu narkomanii, Dz.U. z 2012 r. poz. 124 z późn. zm. [dalej: u.p.n.]. 
nie wykorzystuje w pełni możliwości danych przez prawo polskie. Odpowiednie przygotowanie ustaw na poziomie wszystkich diecezji w Polsce czy też ustaw wewnętrznych diecezjalnych w oparciu o dane dotyczące kondycji społeczeństwa, czyli różnorodnych problemów, zagrożeń, czy rozmaitych zakłóceń życia społecznego oraz przyjęcie określonych rozwiązań prawnych może zapewnić, że działania związane z profilaktyką społeczną będą efektywniejsze.

Nie oznacza to, że Kościół w Polsce niewiele robi w zakresie profilaktyki społecznej. Nieocenioną rolę w tych dziedzinach odgrywają stowarzyszenia wiernych (np. Ruch Światło-Życie) czy programy ewangelizacyjne (np. Krucjata Wyzwolenia Człowieka), które promują określone życiowe postawy. Aktywna przynależność do tego typu grup jest bez wątpienia formą profilaktyki społecznej, tym skuteczniejszej, iż opartej na fundamencie religijnym. Oczywiście działalność profilaktyczna wskazanych grup jest zwykle ich celem pobocznym.

W tym miejscu należy wysunąć postulat wobec kościelnych organów prawodawczych, aby w regulacjach przez siebie stanowionych wykorzystały możliwości, które daje prawo polskie, do pełniejszego włączenia Kościoła i jego struktur w profilaktykę społeczną. Zwiększona efektywność profilaktyki społecznej prowadzonej przez Kościół lub pozakościelne podmioty jest bowiem bardzo pożądana. Wypełnienie tego postulatu będzie realizacją powszechnego prawa kanonicznego, które ma na celu wspieranie przedmiotowych działań poprzez dodatkowe oddziaływanie na wiernych, w celu zachęcenia ich do podjęcia określonych działań czy zajęcia postaw pożądanych z punktu widzenia społeczeństwa. Dodać trzeba, że prawo kanoniczne może nakazywać lub umożliwiać współpracę kościelnych osób prawnych czy innych elementów struktury kościelnej z władzami rządowymi i samorządowymi, z ośrodkami pomocy społecznej czy innymi organizacjami także o genezie kościelnej, czyli stowarzyszeniami wiernych. Bez wątpienia większe zaangażowanie się Kościoła w profilaktykę społeczną może pomóc w wypełnianiu jego misji, a także wzmocnić pozycję Kościoła w Polsce.

\section{Bibliografia}

Borzucka-Sitkiewicz K., Kowalczewska-Grabowska K., Profilaktyka społeczna. Aspekty teoretyczno-metodyczne, Katowice 2013.

Codex Iuris Canonici auctoritate Ioannis Pauli PP. II promulgatus, AAS 75 (1983), cz. 2, s. 1-318; Konferencja Episkopatu Polski, Kodeks Prawa Kanonicznego, tekst łacińsko-polski, Poznań 1984.

Cudak S., Profilaktyka zagrożeń dzieci i młodzieży, Łódź-Warszawa 2015. 
Dudek D., Równouprawnienie kościołów i związków wyznaniowych na tle konstytucyjnych zasad prawa wyznaniowego, [w:] Prawo wyznaniowe w systemie prawa polskiego. Materiaty I Ogólnopolskiego Sympozjum Prawa Wyznaniowego (Kazimierz Dolny, 14-16 stycznia 2003), red. A. Mezglewski, Lublin 2004, s. 199-225.

I Synod archidiecezji białostockiej, Białystok 2000.

II Polski Synod Plenarny (1991-1999), Poznań 2001.

III synod gdański. Misja ewangelizacyjna Kościoła gdańskiego na początku nowego tysiąclecia, t. 1, Statuty, Gdańsk 2001.

IV Synod archidiecezji warszawskiej, Warszawa 2003.

Joannes Paulus PP. II, Litterae apostolicae Redemptor hominis Iesus Christus est centrum universi et historiae, 4 marca 1979, AAS 71 (1979), s. 257-324; tekst polski: Nauczanie Ojca Świętego Jana Pawła II, Komputerowy zbiór dokumentów papieskich, CD-ROM, Wydawnictwo M, wersja 1 z 1999 r.

Katechizm Kościoła Katolickiego, Poznań 2002.

Konferencja Episkopatu Polski, Dyrektorium duszpasterstwa rodzin, dokument przyjęty podczas 322 Zebrania Plenarnego Konferencji Episkopatu Polski dnia 1 maja 2003 r., Warszawa 2003.

Kroczek P., Cele stowarzyszeń wiernych świeckich $i$ ich realizacja na przykładzie wybranych stowarzyszeń działających w Diecezji Bielsko-Żywieckiej, [w:] W prostocie prawdy, w pokorze miłości. Studia i materiały dedykowane księdzu prof. zw. dr. hab. Janowi Walowi, red. T. Borutka, A. Baczyński, M. Ostrowski, Kraków 2008, s. 313-322.

Kroczek P., Kościelne poradnictwo rodzinne: stan prawny i postulaty de lege ferenda, [w:] Wyjechać czy pozostać? Wokół dylematów rynku pracy, red. M. Duda, B. Majerek, Kraków 2015, s. 279-296.

Kroczek P., The art of legislation: the principles of lawgiving in the Church, 2nd rev. ed., Kraków 2012. National Conference of Catholic Bishops, A manual for bishops. Rights and responsibilities of diocesan bishops in the revised Code of canon law, Washington 1992.

Patologie społeczne, przestępczość, niedostosowanie społeczne. Wyzwania dla współczesnej profilaktyki, red. M. Jędrzejko, W. Gładysz, Warszawa 2014.

Pawlak M., Profilaktyka społeczna i resocjalizacja, Warszawa 2014.

Przybysz-Zaremba M., Butvilas T., Profilaktyka narkotykowa w szkole, „Pedagogika Społeczna” 13 (2014) nr 3, s. 105-117.

Rajewska-Nikonowicz E., Gołaszewska E., Profilaktyka instytucjonalna - województwo podlaskie, Białystok 2014.

Sacrosanctum Concilium Oecumenicum Vaticanum II, Constitutio dogmatica Lumen gentium de Ecclesia, 21 listopada 1964 r., AAS 57 (1965), s. 5-75; tekst polski: Sobór Watykański II, Konstytucja dogmatyczna o Kościele Lumen gentium, [w:] Sobór Watykański II, Konstytucje, dekrety, deklaracje, Poznań 1968, s. 105-170.

Sacrosanctum Concilium Oecumenicum Vaticanum II, Constitutio pastoralis Gaudium et spes de Ecclesia in mundo huius temporis, 7 grudnia 1965 r., AAS 58 (1966), s. 1025-1115; 
tekst polski: Sobór Watykański II, Konstytucja duszpasterska o Kościele w świecie współczesnym Gaudium et spes, [w:] Sobór Watykański II, Konstytucje, dekrety, deklaracje, Poznań 1968, s. 537-620.

Sacrosanctum Concilium Oecumenicum Vaticanum II, Decretum Apostolicam actuositatem de apostolatu laicorum, 15 listopada 1965 r., AAS 58 (1966), s. 837-864; tekst polski: Sobór Watykański II, Dekret o apostolstwie świeckich Apostolicam actuositatem, [w:] Sobór Watykański II, Konstytucje, dekrety, deklaracje, Poznań 1968, s. 379-405.

Sacrosanctum Concilium Oecumenicum Vaticanum II, Decretum Presbyterorum ordinis de presbyterorum ministerio et vita, 7 grudnia 1965 r., AAS 58 (1966) 991-1024; tekst polski: Sobór Watykański II, Dekret o posłudze i życiu kapłanów Presbyterorum ordinis, [w:] Sobór Watykański II, Konstytucje, dekrety, deklaracje, Poznań 1968, s. 487-517.

Sacrosanctum Concilium Oecumnicum Vaticanum II, Decretum Christus Dominus de pastorali episcoporum, 28 października 1965 r., AAS 58 (1966), s. 673-696; tekst polski: Sobór Watykański II, Dekret o pasterskich zadaniach biskupów w Kościele Christus Dominus, [w:] Sobór Watykański II, Konstytucje, dekrety, deklaracje, Poznań 1968, s. 232-254.

Skrzydło W., Konstytucja Rzeczypospolitej Polskiej. Komentarz, Kraków 2002.

Urbaniak-Zając D., Piekarski J., Profilaktyka społeczna (prewencja), [w:] Elementarne pojęcia pedagogiki społecznej i pracy socjalnej, red. E. Latak, T. Pilch, Warszawa 2012.

Ustawa z dnia 12 marca 2004 r. o pomocy społecznej, Dz.U. z 2015 r. poz. 163 z późn. zm.

Ustawa z dnia 17 maja 1989 r. o stosunku Państwa do Kościoła Katolickiego w Rzeczypospolitej Polskiej, Dz.U. z 2013 r. poz. 1169 z późn. zm.

Ustawa z dnia 24 kwietnia 2003 r. o działalności pożytku publicznego i o wolontariacie, Dz.U. z 2010 r. Nr 234, poz. 1536 z późn. zm.

Ustawa z dnia 26 października 1982 r. o wychowaniu w trzeźwości i przeciwdziałaniu alkoholizmowi, Dz.U. z 2012 r. poz. 1356 z późn. zm.

Ustawa z dnia 29 lipca 2005 r. o przeciwdziałaniu narkomanii, Dz.U. z 2012 r. poz. 124 $\mathrm{z}$ późn. $z m$.

Ustawa z dnia 5 czerwca 1998 r. o samorządzie województwa, Dz.U. z 2013 r. poz. 596 z późn. zm. Ustawa z dnia 7 września 1991 r. o systemie oświaty, Dz.U. Nr 256, poz. 2572 z późn. zm.

Utrat-Milecki J., Aktualność programu profilaktyki społecznej i resocjalizacji na Uniwersytecie Warszawskim, „Profilaktyka Społeczna i Resocjalizacja” 25 (2015), s. 163-179.

Wach T., Profilaktyka i resocjalizacja nieletnich zagrożonych uzależnieniem od środków psychoaktywnych, Warszawa 2014.

Wijlens M., For you I am a bishop. With you I am a Christian, „The Jurist” 56 (1996), s. 68-91. Wyrok Trybunału Konstytucyjnego z dnia 14 grudnia 2009 r., K 55/07, Legalis nr 180038. Wyrok Trybunału Konstytucyjnego z dnia 7 czerwca 2004 r., P 4/03, Legalis nr 63693.

Zajdel-Ostrowska M., Profilaktyka instytucjonalna w woj. podkarpackim w 2013 r., Rzeszów 2014. 
4. Uniwersytet Papieski 